\title{
EDUCATIONAL ACTIVITIES OF THE INTERNATIONAL CARPATHIAN SCHOOL IN THE CONTEXT OF SUSTAINABLE DEVELOPMENT GOALS
}

\author{
Valeriy Mykhaylenko, Mykola Blyzniuk
}

\begin{abstract}
International Carpathian School is a fast-growing volunteer project in Kosiv, Ivano-Frankivsk region, Ukraine, designed as a local centre of non-formal education to address youth adaptation to the globalized world. It intended to overcome the existing gaps in the education of socially conscious youth, finding optimal ways of skill-sharing activities to local communities. Among others, the school is oriented for delivering knowledge, skills and attitudes of the EU best practices in the field of municipal solid waste management (MSWM). In a broader meaning, the Carpathian School Agenda serves for the environmental protection of the vulnerable mountain landscapes to meet the Sustainable Development Goals Ukraine-2030 (hereof and after SDG), entered in force by the Decree of the President of Ukraine in order to ensure the national interests of Ukraine in relation to sustainable economic development [1]. The School activity is aligned with both SDG-4 "Quality education" and SDG-11 "Sustainable cities and communities". It has an interdisciplinary approach to learning where academic concepts of geoscience are coupled with real-world lessons. Carpathian Winter School hosted researches from Ukraine, Georgia and Armenia together with five educational entities from Baltic Sea Region (BSR). Scholars were exposed to a cross-cultural experience that facilitates connections between the classroom and the world around them. Simultaneously, the School is providing a prospect to local scientists in maintaining professional links with their foreign colleagues and obtaining hands-on scientific information on MSWM. Having a central geographical position and well-developed informal tuition activities, the Carpathian School may have a good chance to become a placement for students' mobility, people-to-people contacts and promoting youth employability that is coherent with The Eastern Partnership (EaP) policy [2]. The educational project of the Swedish Institute LASUWAMA [3], which was considered at the Carpathian Winter School, combined researchers from Ukraine, Georgia and Armenia. Representatives of EU universities, involved in the development of educational programs, provided the relevant knowledge and skills, needed to students for gaining an in-depth understanding of the sustainable development concept [4], including, inter alia, access to further vocational training in EU countries
\end{abstract}

Keywords: Education, University, Waste management, Landfill, Landscape, Sustainability, Transfer technologies

How to Cite:

Mykhaylenko, V., Blyzniuk, M. (2021). Educational activities of the international Carpathian school in the context of sustainable development goals. ScienceRise: Pedagogical Education, 2 (41), 4-9. doi: http://doi.org/10.15587/2519-4984.2021.228131

(C) The Author(s) 2021

This is an open access article under the CC BY license (http://creativecommons.org/licenses/by/4.0).

\section{Introduction}

Over the past decades, the global trend of scientific and educational research lies in the field of education for sustainable development (ESD) [5]. Nearly all universities had been reformed their curricula and introducing new forms of academic recognition and quality assurance of education. Municipal solid waste management (MSWM) takes one of the most important environmental concerns in global and regional dimensions. It is recognized as one of the most challenging areas in the European Union (EU) member states and also in Eastern Partnership (EaP) countries of Central and Eastern Europe. The multidimensional nature of MSWM has stipulated many problems in EaP countries that are seeking progressive integration into the civilized European space.

In 2012 European Commission presented its Rethinking Education Strategy, which called for a fundamental shift in education and a greater focus on "learning outcomes" that can help to solve $21^{\text {st }}$-century problems. Since 2015, the universities are recognized ESD as a driving force that unites educational entities of formal and informal education; and adapted educational materials to the human resources needs.

Waste management as a final phase of consumption of natural resources is an essential part of the environmental balance that indicates the quality of life and cultural level of civilised society. Achieving the Sustainable Development Goals (SDGs) is about producing tangible results that improve people's lives in EaP countries. This is a dynamic process of adaptation, learning and action [6]. Attainment of the SDGs requires support at the highest level and involvement of all relevant actors in society, responsible for equitable social development; sustainable economic growth and employment; effective, accountable and inclusive management for gaining the environmental balance.

The SDGs should ensure the national integration of efforts for economic growth and the need for environmental management. International donors often played an important part in speeding these trends.

This publication aimed at discussing measures, suggested by an international project entitled "Strengthening BSR Universities Network on Landscape Sustainabili- 
ty and Waste Management" (acronym LASUWAMA) to achieve objectives of Goal 4 "Quality education" and Goal 11 "Sustainable cities and communities" in participating EaP countries [3].

\section{Literary review}

Achieving SDG-30 is about producing tangible results that improve people's lives in the Eastern Partnership (EaP) countries [5]. This is a dynamic process of adaptation, learning and action [6]. In a wide context, the EaP supports delivery on key global policy goals, set by the UN 2030 SDG and the Paris Agreement on Climate Change [7].

ESD is one of the key aspects of the curriculum in modern Western European universities. The formation of an active civic position requires innovative approaches in education. Currently, there is no universal model of ESD. The dominant function in this process should be provided by universities as carriers of multidisciplinary disciplines $[8,9]$. The special emphasis of the Carpathian School is placed on Quadruple Helix Cooperation that is considering universities as drivers of a sustainable society [10].

The transition from a totalitarian system to democratic governance and ensuring the principles of SD is very slow and ambiguous in Ukraine. The reality of nowadays clearly reflects the urgency to put in place the ESD principles into all levels of education.

Mountains are highly vulnerable to human and natural ecological imbalance. Management-related activities foresee encouraging policies that would provide incentives to local people to undertake conservation and regenerative measures [4]. Social problems are common to EaP countries that faced with the problem of poor population that loses the resource for existence. So, solving the environmental problem, reducing the load on the landfills, is worth discussing the topic of how to find an expedient way to help the poor and homeless.

Ukraine. According to official data, Ukraine produces about 45 million $\mathrm{m}^{3}$ of waste annually, which is buried on 6.7 thousand dumps and landfills with a total area of more than 10 ha. The footprint of MSW landfills is up to over a thousand ha [11].

An exit pole, provided recently in Ukraine, indicated that about $48.8 \%$ of the polled citizens responded that waste management has the most priority among environmental problems [12]. The increasing of bulk waste takes the second place among the most acute environmental problems (37.4\% of respondents). Most of the efforts now focus on developing a new waste management policy by adopting appropriate strategies and plans that reflect the main European principles and approaches in this area.

The Ukrainian Government has approved the National Waste Management Strategy in 2017. The strategy provides the organization of separate waste collection in 5000 settlements by the 2030 year, construction of 240 waste reception centres and 735 waste recycling facilities, closing and reclamation of existing $5700 \mathrm{MSW}$ landfills. The level of MSW recycling should increase to $20 \%$ of the total volume (2017 - 3.04 \%). The declared MSWM policy is not coherent with the social behaviour of citizens. Only $35.7 \%$ of Ukrainian residents are separate household waste at home, although $60.2 \%$ believe that this daily practice will help to preserve the environment in Ukraine. There are $29.1 \%$ of citizens, who avoid buying disposable plastic products, and almost half of respondents (48.2\%) still use disposable plastic bags [12].

Today, the development of mountainous areas is one of the tasks, defined in Ukraine by the State Strategy for Regional Development for the period up to 2020. Local authorities are already actively working based on the new A Macro-regional Strategy for the Carpathian region [13].

Georgia. Waste management is one of the main problems that face Georgia. Landfilling is the basic technique of MSW waste disposal. Waste is placed on municipal landfills without any sorting or separation. It is not compacted, covered or insulated due to lack of machinery. The MSW cleaning service is applied mainly in large cities and district centres, such as Tbilisi, Kutaisi and Batumi. Many old landfills do not follow basic waste management standards. The majority of landfills are lack of leachate drainage and collection systems.

Rural residents usually arrange landfills in adjacent ravines, along the road, or on the banks of rivers, so there are hundreds of uncontrolled spill dumps in the country. There are no incineration technologies yet, and only some types of wastes, such as oil waste, plastic and packaging, are processed in limited quantities by private companies. Polluted groundwater is one of the linked concerns that is posing a serious threat to the local water streams and contaminates international water bodies. The Poti city landfill is the exact cause. It lis ocated at the Rioni river bank without any precautions to avoid leachate pollutants.

Continuing public information and education initiatives are required to encourage people to change how they live, to become more sustainable.

Armenia. The Republic of Armenia has hundreds of landfills and various dumpsites across the country. To date, not one has been constructed to even the minimal accepted industry standards. In the urban areas, there is a real and growing potential for a public health calamity. Uncontained leachates, dangerous methane build-ups and uncontrolled burning are all capable of introducing toxins into the air, streams and water tables around densely populated areas. Recycling inorganic waste is one way forward with major potential [14].

Solid waste management also remains the most problematic challenge for Armenian cities. To illustrate, a baseline study of 40 Armenian cities showed that it remains the first service priority for 33 of these cities [15]. The main problems in this field can be grouped into four performance areas:

1) lack of legislative background and a poor management system,

2) lack of appropriate equipment,

3) lack of financial capacities, and

4) a weak relationship with the public in the cities. No waste sorting, recycling, or reuse takes place at any of them. Instead, garbage is dumped into a working area and then flattened using a bulldozer to create a layer of garbage three meters thick [16]. The baseline data and analysis of 24 cities showed that in some cities there were no services at all in the districts with private houses.

There should be no serious obstacles to incorporating the recycling component in MSW collection and disposal service in Armenia. Recycling in Armenia has attractive prospects. According to the ESIA report, the decision to include recycling or waste sorting as an op- 
tion was ultimately rejected "due to affordability constraints, resulting from limited financial resources". Citing "the absence of suitable district heating networks", as well as high operation and maintenance costs, the alternative solution of waste incineration, linked with energy production for heating, was also not selected [17].

Carpathian School. ESD is gradually being introduced in Ukraine, which envisages the development of civil society and the active role of the public in the processes of socio-economic development of the country. This direction is actively implemented by the Carpathian School that collect participants in the foothills of the Ukrainian Carpathians in both Ivano-Frankivsk and Chernivtsi regions within four last years.

Following conceptual thinking to the landscape as a physical outcome of the mutual interaction between nature and people in a particular area, we are sure that the landscape can be considered as the physical environment of the people, who live and work in that area. We are using the concept of landscape services $[7,8]$ throughout this paper to denote the connection of the functioning of landscapes to the benefits, valued by society. In this context, the quality of landscapes means the quality of living conditions that are assumed to be sustainable.

The Faculty of Geography of the Taras Shevchenko National University of Kyiv arose the idea to hold a joint Carpathian School together with local government and regional environmental organizations. This statement lies in line with the regional development of Ivano-Frankivsk oblast. An Agency for the Regional Development of the Ivano-Frankivsk region was created to enhance the social and economic progress of the Carpathian region [17].

\section{Research aim and tasks}

This study aims to introduce ESD as a tool for transferring the EU best practice in municipal waste management to the local mountain area of Ukraine, Georgia and Armenia through gaining knowledge and establishing a dialogue among the LASUWAMA participating countries.

The Carpathian School international Board elaborated the tuition plan that included the LASUWAMA segments on Sustainable waste management; Energysaving technologies; Adapting to climate change Landscape remedial operations; and MSWM best practice.

To achieve the stated goal, we aim to fulfil the following objectives:

1. Defining the stakeholder groups for operations within the Quadruple Helix model.

2. Introducing the SDGs-2030 through gaining knowledge and establishing a dialogue within the LASUWAMA project.

3. Establishing direct international links among the universities, civic organizations, local communities, practitioners and local officials that may bring synergy effect to transfer MSW technologies to the vulnerable mountain regions.

4. Promoting the practical implementation and dissemination of innovation; to develop international relations to create bases for engineering practice and testing of scientific research results

5. Strengthening collaborative activity among Ukrainian local stakeholder's groups, such as local uni- versities, National Natural Parks, Civic Society Organisations (CSO), practitioners and local government.

\section{Research methodology and methods}

One of the project activities is going to take place at Carpathian Winter School, traditionally conducted in Kosiv, a small town of Ivano-Frankivsk district, Ukraine. The targeting group is Master and $\mathrm{PhD}$ students, the nominees from the participating universities of Sweden, Estonia, Lithuania, Latvia, Ukraine, Georgia and Armenia, together with their tutors and practitioners. The supplementary stakeholders will include representatives of The Ministry of Environment and Natural Resources of Ukraine, Local Government officials, together with the invited local experts and practitioners in MSWM. The representatives of Ukrainian local environmental organizations that are securing the interests of civil society in the mountain region also will welcome.

The Carpathian School international Board elaborated the tuition plan that included the LASUWAMA segments on Sustainable waste management; Energysaving technologies; Adapting to climate change Landscape remedial operations; and MSWM best practice.

Learning materials, scientific papers, presentations, videos and photo information were collected at the School depository to be available for distant learning.

\section{Research results of their discussion Quadruple Helix Cooperation}

The LASUWAMA project is encompassing the listed above EaP countries and relates to the bilateral reference documents that will steer EaP CSF's work for the period 2018-2020. The project objectives are to expose Master and $\mathrm{PhD}$ students to multidisciplinary educational curricula that share the best practice experience of the BSR countries. It foresees a combination of off-the-shelf training materials in the area of municipal services, engineering, environmental management, global concerns and trans-boundary cooperation, aiming to meet the EU strategy for the BSR, the EU`s Eastern Partnership and also UN SDGs by 2030 year.

The world experience of the developed countries, as well as those in a transitional state, proves the efficiency and regularity of the emergence of cluster models in education. The formation of educational clusters has become an important part of the state personnel policy of many countries of the world. In Ukrainian realities, universities are the most suitable for the role of educational clusters, which should become research sites, research centres, open to innovations and new educational technologies [8, 18].

A combination of experienced educational entities from the BSR with their EaP counterpart countries is a fruitful idea. It foresees building the capacity of academic tutorials and supplementary resources, expanding distant learning technologies and making use of students mobilities for site visiting, attending international conferences, schools and workshops. Special emphasis is placed in focusing on Quadruple Helix Cooperation that is considering universities as a driver of sustainable society [19]. In the conditions of uneven territorial development, only synergy activities of the state and local governments, scientists, business and public organizations can drive rural mountains communities to 
achieve sustainable socio-economic development. An urgent need is to apply an integrated approach to the development of mountain areas, based on determining their priority at the present stage. It is also necessary to solve the issue of forming an institutional environment for the development of mountain areas, which is an important prerequisite for their balanced progress.

Quadruple Helix Cooperation is an affordable way to strengthen the institutional capacity of the mountain communities. In our opinion, the negative tendencies of MSWM in EaP countries can be slowed down by consolidating the efforts of educational institutions of formal and informal education, intensifying international corporate ties, introducing modern educational technologies, new academic disciplines and adapting educational materials, developed in the BSR. An important segment is also the improvement of the skills of teachers, officials and managers.

Carpathian School is a successful example of a combination of educational tools, delivered to the audience by local universities, sharing best practice of Kaunas University of Technology and Estonian University of Life Sciences in landfill mining.

Carpathian School is also assisting local communities in strengthening environmental governance by fostering civic involvement and transparency in governmental decision-making and educating a variety of stakeholders, including schoolchildren, their families, local environmental organisations about sustainable use of natural resources and advanced waste management technologies.

\section{Transfer technologies}

Technology transfer is the mechanism for bringing knowledge from one research area to another, from industry developed countries to developing countries. This mechanism is not simply copying of technology, chains or sequence of operations. It means accepting that knowledge through social and behavioural research, organize and diffuse information, taking into account national features, local conditions, cultural and moral features. The global waste management practices applied up to 50 varieties of MSW technologies, processes and types of facilities. The majority of them are staying in line to be recognized and absorbed by EaP countries. Speaking of achieving SDG-30, it means fostering learning abilities of the $\mathrm{EaP}$ countries, realizing transmission of knowledge through transfer technologies and ensuring effective use of that knowledge.

MSW processing in EaP countries does not yet involve the application of high technologies, so acceptance of European practices, effective implementation of reforms and completion of existing projects, can boost rapid growth in the industry. We do believe that case studies, presented by the BSR experts at the Carpathian School, may attract communities, located in mountain districts. Some of them are listed below.

Landfill mining, Sweden. The Environmental Science \& Engineering Group (ESEG) at Linnaeus University is experienced in closing the landfill life cycle (landfill mining) since 2012. The PHYTECO project was designed to develop a remediation strategy for the development of the recreation park at the placement of the old glass dump. Here designers, scientists, local volunteers and international students joined ideas and commonly worked for the boost of innovation and sustainable thinking [20].

The Orrefors project, Sweden. The Orrefors glass factory during its performance created a lot of pollution in the surrounding area. Dumps emerged all around the village that affected the soil, water and all environmental quality. This project was a cooperation among different Quadruple Helix entities - academia, business companies and decision-makers in Sweden, Latvia, Ukraine and Estonia are collaborating in research and education with a focus on ecological sustainability in glasswork regions that are contaminated with heavy metals.

The Kudjape landfill mining project, Estonia. This project is particularly interesting to communities living in mountains that have limited soil amounts. It also may serve as a good example of the previous successful co-operation of Linnaeus University, Sweden with Estonian, Latvian and Ukrainian universities [21].

Phytoremediation, Latvia. Phytoremediation gives a chance to rehearse the scheme of action for further application in other countries. This is relatively inexpensive and easy to use technology that can transform cosy places into pleasant for visiting tourists and residents. One of the most applicable territories for such reclamation is mountains and the spoil tip (a pile for stacking waste rock, brought to the earth's surface from mines and pits).

Lifescape project, Lithuania. Good practices and outcomes of the Lifescape project, a transnational initiative to foster the implementation of the European Landscape Convention in the South Baltic Region that has been carried out in Poland, Lithuania, Sweden and Denmark.

\section{Conclusions}

The School curricula will focus on landscape policy and remediation strategy for mountain regions through sharing the knowledge and best practice among the involved universities, their students and local stakeholders groups. It may support capacity-building activities by securing dissemination of new knowledge and furthering international networking beyond that, which universities already do by themselves. Thus, the educational activities of the school contribute to the achievement of all five priority areas of SDG-2030 in Ukraine:

1. The Carpathian School Agenda is integrated into international and national policies related to ESD.

2. The four-dimensional model of informal education, training of different stakeholders and age categories are applied. Emphasis on the need to work together, as provided by a Quadruple holistic model of cooperation (education - power - business - community), is placed.

3. Expanded opportunities for partner universities as organizers of education to transform public consciousness are provided.

4. New educational technologies have been introduced to the scholars of the local lyceum.

5. Educational activities, taking place directly in communities, are the driving force for achieving the ambitious SDG-2030. 
The LASUWAMA project enlarged the Carpathian School curricula with capacity-building activities by securing dissemination of new knowledge and furthering international networking beyond that, which universities already do by themselves. The School improved national and international professional networks between academia and business, thereby making education, research and innovation the key driving mechanisms in sustainable MSW management and achieving the international SDG4 "Quality education".

\section{Acknowledgements}

The Swedish Institute, supported the Linnaeus University Kalmar, Sweden, to provide the LASUWAMA, PHYTECO and PECEC projects.

The Academic Mobility Office and Student Parliament of the Taras Shevchenko National University of Kyiv, Ukraine, provided organisational support to the KNU students' academic mobility.

The Kosiv Centre of Civic Initiative, provided its organizational and human resources.

\section{References}

1. Pro Tsili staloho rozvytku Ukrainy na period do 2030 roku (2019). Ukaz Prezydenta Ukrainy No. 722/2019. 30.09.2019. Available at: https://zakon.rada.gov.ua/laws/show/722/2019\#text

2. Eastern Partnership. European Neighbourhood Policy And Enlargement Negotiations. Available at: https://ec.europa.eu/ neighbourhood-enlargement/neighbourhood/eastern-partnership_en

3. LASUWAMA; Strengthening BSR Universities Network on Landscape Sutainability and Waste Management Swedish Institute (2019). Awailable at: https://si.se/en/projects-granted-funding/lasuwama-strengthening-bsr-universities-network-on-landscape-sutainabilityand-waste-management

4. Agenda XXI (2019). United Nations Conference on Environment \& Development. Rio de Janerio, 351. Available at: https://sustainabledevelopment.un.org/content/documents/Agenda21.pdf

5. Kopnina, H., Meijers, F. (2014). Education for Sustainable Development (ESD): Exploring Theoretical and Practical Challenges. International Journal of Sustainability in Higher Education, 15 (2), 188-207. doi: http://doi.org/10.1108/ijshe-07-2012-0059

6. Global Sustainable Development Report (2015). Briefs 2015: Brief 2. Integrated Perspectives on Sustainable Development Goals. Available at: https://sustainabledevelopment.un.org/content/documents/1870GSDR\%202015\%20Briefs.pdf

7. Adoption Of The Paris Agreement (2015). United Nations. Available at: https://unfccc.int/sites/default/files/english_ paris_agreement.pdf

8. Agamuthu, P., Hansen, J. A. (2007). Universities in capacity building in sustainable development: focus on solid waste management and technology. Waste Management \& Research: The Journal for a Sustainable Circular Economy, 25 (3), $241-246$. doi: http://doi.org/10.1177/0734242x07079155

9. Hansen, J. A., Lehmann, M. (2006). Agents of change: universities as development hubs. Journal of Cleaner Production, 14 (9-11), 820-829. doi: http://doi.org/10.1016/j.jclepro.2005.11.048

10. König, J., Suwala, L., Delargy, C.; Leal Filho, W., Azul, A., Brandli, L., Lange Salvia, A., Wall, T. (Eds.) (2020). Helix Models of Innovation and Sustainable Development Goals. Industry, Innovation and Infrastructure. Encyclopedia of the UN Sustainable Development Goals. Cham: Springer. doi: http://doi.org/10.1007/978-3-319-71059-4_91-1

11. Minregion of Ukraine. Statistics of 2016. Available at: http://www.minregion.gov.ua

12. Environmental Portrait of the Ukrainian Citizen: Comparison with the EU and Recommendations (2018). Resource and Analysis Center "Society and Environment", 11. Available at: http://www.rac.org.ua/uploads/content/485/files/envportraitexsum2018.pdf

13. Jourde, P., Van Lierop, Ch. (2019). A macro-regional strategy for the Carpathian region. European Parliament. Think Tank. Available at: https://www.europarl.europa.eu/thinktank/en/document.html?reference=EPRS_BRI(2019)642257

14. Waste Management. Armenian Environmental Network. Available at: https://www.armenia-environment.org/proj-pagewaste-management/

15. Armenia Local Government Program (2006). RTI International Phase 3, Baseline Review. USAID.

16. Vanoyan, M., Varosyan, A., Petrossian, A. (2010). Solid Waste Management in Armenian Cities. Phase 3. USAID-Armenia. Available at: https://www.pf-armenia.org/sites/default/files/uploads/pfa_uploads/tasima15_beitrag_USAID_2010_08-26.pdf

17. Mykhaylenko, V., Denafas, G., Kriipsalu, M., Turkadze, T., Grinfelde, I., Horttanainen, M. et. al. (2018). Carpathian school as a tool for achieving sustainable development goals - 2030 in mountain regions of eastern Europe countries. EcoTech-2018, 37.

18. Khmara, M. (2015). Development of Educational Clusters in Ukraine. Journal of Global Economy Review, 1 (4), $84-89$.

19. Etzkowitz, H. (2008). The Triple Helix: University-Industry-Government Innovation. New York: Routledge, 180. doi: http://doi.org/10.4324/9780203929605

20. PHYTECO project regenerates glassworks site (2015). Swedish Institute.

21. Hogland, M., Hogland, W., Jani, Y., Kaczala, F., De Sá Salomão, A. L., Kriipsalu, M. et. al. (2014). Experiences of three landfill mining projects in the baltic sea area: with focus on machinery for material recovery. Linnaeus Eco-Tech. Kalmar. doi: http://doi.org/10.15626/eco-tech.2014.014

Received date 16.02.2021

Accepted date 22.03.2021

Published date 31.03.2021

Valeriy Mykhaylenko, PhD, Associate Professor, Department of Physical Geography and Geoecology, Taras Shevchenko National University of Kyiv, Volodymyrska str., 60, Kyiv, Ukraine, 01033,

E-mail: v.mykhaylenko@gmail.com

Mykola Blyzniuk, Doctor of Pedagogical Sciences, Associate Professor, Department of Production and Information Technologies and Life Safety, Poltava V. G. Korolenko National Pedagogical University, Ostrogradskoho str., 2, Poltava, Ukraine, 36003, Email: Blyzniyk@ gmail.com 